\title{
Deep cytogenetics analysis reveals meiotic recombination depletion in species of Senecio (Asteraceae)
}

\author{
Mariana G Lopez ${ }^{1,3}$, Cecilia C Xifreda ${ }^{2}$, Lidia Poggio ${ }^{1}$ and Arturo F Wulff ${ }^{1,4^{*}}$
}

\begin{abstract}
Background: Senecio is the largest genus in the Asteraceae family growing in all environments around the world. It displays taxonomic and systematical difficulties. Cytogenetic knowledge of this genus is ancient, scarce and mainly restricted to chromosome number records.

Results: In this study we analyzed chromosome number, meiotic configuration, bivalent morphology, meiotic behavior and pollen grain stainability on 100 accessions of 27 different polyploid Senecio L. sect Senecio entities. Median, standard deviation and mode were calculated for number and position of chiasmata and meiotic recombination was statistically evaluated. Although high frequency of multivalents and associated meiotic irregularities are expected in high polyploids, bivalents predominance and, consequently, regular meiosis were observed, with normal sporogenesis and high pollen grain stainability.

Conclusion: Depletion in the total chiasmata was significant only in some species but the terminal position was preferential in all the entities analyzed, indicating significant reduction in recombination. The regular meiosis observed suggest that intra and intergenomic reorganization process occur quickly and efficiently in this genus. Mechanisms of diploidization, common to all polyploids, are reinforced by the strong reduction in crossing-over rushing polyploids stabilization.
\end{abstract}

Keywords: Chiasmata; Chromosome number; Cytogenetics; Meiotic analysis; Meiotic recombination; Senecio

\section{Background}

Senecio L. is a cosmopolitan genus described by Linné in 1753. It grows in all the regions with the exception of South Pacific Islands and Antarctica, although shows the highest specific richness in the mountain areas (Cabrera et al., 1999). The number of species belonging to Senecio is controversial, ranging from 1000 to up 3000, mainly because the extremely difficult taxonomy and systematics. Nevertheless this debate, different authors agree that it is the largest genus of the Asteraceae family

\footnotetext{
* Correspondence: artulf@ege.fcen.uba.ar

${ }^{1}$ CONICET, Laboratorio de Citogenética y Evolución (LACyE), Departamento de Ecología, Genética y Evolución, Facultad de Ciencias Exactas y Naturales, Universidad de Buenos Aires, Ciudad Universitaria, Pabellón 2, $4^{\circ}$ piso, Int. Güiraldes 2620, C1428EHA, Buenos Aires, Argentina

${ }^{4}$ Laboratorio de Citogenética y Evolución (LACyE), Departamento de Ecología, Genética y Evolución, Facultad de Ciencias Exactas y Naturales, Universidad de Buenos Aires, Ciudad Universitaria, Pab. II, $4^{\circ}$ piso. Lab 61, Intendente Güiraldes 2160, (C1428EHA), Buenos Aires, Argentina Full list of author information is available at the end of the article
}

(Bremer 1994; Cabrera et al., 1999; Nordenstam, 2007; Pelser et al., 2007). Medicinal, ornamental, noxious plants and weeds fit into this group giving it, in addition to the ecological value, an economical interest. At the cytogenetic level the modal chromosome numbers in Senecio are $2 n=40$ and $2 n=80$ (Bolkhovskikh et al., 1974). Polyploidy is one of the most notorious features in the genus (Lawrence, 1980; 1985) and $\mathrm{x}=5$, the accepted basic chromosome number (López et al., 2008a). Even when in the last years some works were published, mostly about Argentine species (López et al., 2002; 2005; 2008a; 2008b) cytogenetic knowledge of Senecio in the world is still scarce and ancient (see López, Citogenetics, Evolutive and Biosistematical Studies in Senecio sect. Senecio serie Corymbosi, from Argentina. 2008. Unpublished PhD Thesis University of Buenos Aires. Argentina for complete revision) and mainly restricted to chromosome number records. It has been suggested that deeper cytogenetic analyses would be very useful in order to understand the 
evolution and clarify the taxonomic complexity in this diverse taxon (López et al., 2008a; 2008b).

Polyploidy has received special interest during the last decade, assigning it the main role in relation to the evolution of the angiosperms. It is considered an important speciogenic force and the major source of genetic variability in plants (Heslop-Harrison Pat and Schwarzacher 2011). Otherwise the old thoughts emphasized variability in the combination of genomes occurring in polyploids (Stebbins, 1980; Grant, 1989), more recent approaches highlight the recurrent formation of polyploids (Ashton and Abott 1992), the huge genomic reorganization caused by the interaction between genomes and the epigenetic modification as central resources of variability associated to polyploidy (Soltis and Soltis, 1999; Wendel 2000; Soltis et al., 2003; Kovarik et al., 2005; Tate et al., 2005; Hegarty et al., 2006; Chen et al. 2007).

A lot of knowledge about Senecio has been generated from molecular data. On the other hand, cytogenetic behavior in polyploids and the consequences of the chromosome genomic rearrangement are less understood. In this sense, previous studies revealed chiasmata excess in taxa from this genus and suggested a chromosome exchange preferentially placed in terminal position (López et al., 2005). Since both events are determinant in the chromosome recombination, their estimation result extremely interesting because could explain the sterility avoidance caused by meiotic alterations, and therefore the maintenance and success of polyploidy species in the nature.

Since Senecio is a genus plenty of polyploid species and notably successful worldwide, our main interest is to present a detailed cytogenetic characterization of several of its species, with special emphasis in the meiotic features, with the objective of understand the task of chromosomes in their success and permanence.

\section{Methods}

\section{Plant material}

Plant materials, including 27 entities, were collected between 2001 and 2006 in different provinces of Argentina (Appendix 1). Voucher specimens were identified, labeled and deposited at the herbaria SI or BAFC. Young capitula were fixed in situ in ethanol-chloroform-glacial acetic acid (6:3:1) for at least $24 \mathrm{hs}$, transferred to ethanol $70 \%(\mathrm{v} / \mathrm{v})$ and stored at $4^{\circ} \mathrm{C}$ until used.

\section{Meiotic studies}

Preparations were obtained squashing immature anthers in a drop of a $2 \%$ propionic acidhaematoxylin solution and using ferric acid as mordant (Núñez 1968). Cytogenetic analyses were performed taking into account a minimum of 50 pollen mother cells (PMCs) per species at different meiotic stages. Slides were observed and photographed using an optic photomicroscope Leica BMLD and a Leica DFC 350 FX digital camera. This study included determination of chromosome numbers, meiotic configurations, bivalents morphology and meiotic behavior. Median, standard deviation and mode were calculated for the number and the position of chiasmata. Pollen grain stainability was studied with Alexander's differential staining method (Alexander, 1969).

In order to evaluate statistically the meiotic recombination, we apply a sample population proportion test (Daniel, 1999). The statistic " $\mathrm{z}$ " used in this test was calculated with the following formula:

$$
z=\frac{\hat{\mathrm{p}}-\mathrm{p}}{\sqrt{\frac{\hat{\mathrm{p}} \hat{\mathrm{q}}}{\mathrm{n}}}} \quad \begin{aligned}
& \hat{\mathrm{p}}=0,5 \\
& \mathrm{p}=1-\hat{\mathrm{p}}=0,5
\end{aligned}
$$

We tested two hypotheses, taking into consideration that the number and the position of chiasmata occurs randomly (i.e. $\mathrm{p}=0.5$ ), as is expected in the meiotic process. For the first hypothesis, z1 was defined as the proportion of open bivalents and in the second one, $\mathrm{z} 2$, as the proportion of interstitial chiasmata. In order to minimize the differences in chiasmata occurrence during meiosis, open bivalents and chiasmata position were determined mainly in diakinesis and also in prometaphase I, in cells where those items could be undoubtedly determined. Previous published chromosome number reports were included in this report in order to enlarging the discussion of this cytogenetic study and the meiotic recombination analysis.

\section{Results}

\section{Chromosome numbers and meiotic configurations}

Complete cytogenetic analysis is summarized in Table 1. Only two different sporophytic numbers (2n) were observed, $2 n=40$ and $2 n=80$. New records on chromosome number were presented for: $S$. eruciformis var. brachycephalus (Figure 1A), S. eruciformis var. eruciformis (Figure 1B), S. grisebachii var. schizotus (Figure 1C), S. linariifolius var. subtomentosus (Figure 1D), S. glaber (Figure 1E), S. riojanus (Figure 1F), S. ganganensis (Figure 1G), S. goldsackii (Figure 1H), S. grisebachii var. leptotus (Figure 1I); S. brasiliensis var. tripartitus (Figure 1J) and S. melanopotamicus (Figure 1K) with $2 \mathrm{n}=40 ;$ S. subulatus var. salsus (Figure $1 \mathrm{~L}$ ), S. viridis var. viridis (Figure $1 \mathrm{M}$ ) and S. microphyllus (Figure $1 \mathrm{~N}$ ) with $2 \mathrm{n}=80$ and, $S$. subulatus var. erectus which exhibited cytotypes with both chromosome numbers (Figure 1O-P, Table 1). Polymorphism for B chromosomes was also observed in some entities (Table 1, Figure 1I, 1N). Although diverse meiotic figures were identified, from univalents (I) to hexavalents (VI) and one decavalent (X), bivalent (II) was the most frequent chromosome pairing (Table 1, Figure 1A-P). Interstitial chiasmata and close 
Table 1 Meiotic analysis and pollen stainability of entities belonging to different Subseries of Senecio sect. Senecio

\begin{tabular}{|c|c|c|c|c|c|c|c|}
\hline \multirow[t]{2}{*}{ Species } & \multirow[t]{2}{*}{$2 n$} & \multirow[t]{2}{*}{ Meiotic configuration } & \multicolumn{2}{|c|}{ Chiasmata/cell } & \multicolumn{2}{|c|}{ Interstitial ch. } & \multirow{2}{*}{$\begin{array}{l}\text { Pollen } \\
\text { stainability }\end{array}$} \\
\hline & & & $\overline{\mathrm{x}} \pm \mathrm{sd}$ & $\bar{M}$ & $\overline{\mathrm{x}} \pm \mathrm{sd}$ & $\bar{M}$ & \\
\hline \multicolumn{8}{|c|}{ Subserie Brasiliensis (Cabrera) Cabrera et S.E. Freire } \\
\hline \multirow[t]{3}{*}{ S. brasiliensis var. tripartitus** $(4,28)$} & 40 & 20 II (92.8\%) & $27.5 \pm 2.4$ & 30 & $4.2 \pm 2.3$ & 4 & $96.1-99.4 \%$ \\
\hline & & $19 \|+2 \mid(3.6 \%)$ & $\left(z_{1}=-1.04\right)$ & & $\left(z_{2}=4.99\right)^{++}$ & & \\
\hline & & 18 II + 4 | (3.6\%) & & & $(0-9)$ & & \\
\hline \multirow[t]{4}{*}{ S. eruciformis var. brachycephalus ${ }^{* *}(2,70)$} & 40 & 20 || (87.1\%) & $24.9 \pm 3.5$ & 24 & $3.0 \pm 2.2$ & 2 & $98.4-99.6 \%$ \\
\hline & & $19 \|+2 \mid(10 \%)$ & $\left(z_{1}=-2.19\right)^{++}$ & & $\left(z_{2}=5.37\right)^{++}$ & & \\
\hline & & 17 II + 1 IV + 2 I (1.45\%) & & & $(0-9)$ & & \\
\hline & & $18 \|+1|| I+1$ I (1.45\%) & & & & & \\
\hline \multirow[t]{3}{*}{ S. eruciformis var. eruciformis** $(2,60)$} & 40 & 20 || (91.7\%) & $26.1 \pm 2.8$ & 29 & $2.6 \pm 2.6$ & 1 & $97.4-98.3 \%$ \\
\hline & & 19 || + 2 | (8.3\%) & $\left(z_{1}=-1.63\right)$ & & $\left(z_{2}=5.49\right)^{++}$ & & \\
\hline & & & & & $(0-12)$ & & \\
\hline \multirow[t]{3}{*}{ S. ganganensis ${ }^{* *}(1,45)$} & 40 & 20 || (93.3\%) & $29.5 \pm 2.0$ & 30 & $3.3 \pm 2.1$ & 4 & $98.90 \%$ \\
\hline & & 18 II + 4 I (4.5\%) & $\left(z_{1}=-0.11\right)$ & & $\left(z_{2}=5.28\right)^{++}$ & & \\
\hline & & 19 || + 2 I (2.2\%) & & & $(0-9)$ & & \\
\hline \multirow[t]{4}{*}{ S. gilliesianus $(4,54)$} & 40 & 20 || (94.45\%) & $31.7 \pm 3.2$ & 33 & $8.8 \pm 2.1$ & 10 & $92.1-98.8 \%$ \\
\hline & & 19 || + 2 | (1.85\%) & $\left(z_{1}=0.81\right)$ & & $\left(z_{2}=3.52\right)^{++}$ & & \\
\hline & & 18 II + 1 IV (1.85\%) & & & $(2-17)$ & & \\
\hline & & 16 II + 2 IV (1.85\%) & & & & & \\
\hline \multirow[t]{3}{*}{ S. glaber** $(1,17)$} & 40 & 20 II (100\%) & $32.0 \pm 2.2$ & 31 & $6.7 \pm 4.2$ & 3 & $83.40 \%$ \\
\hline & & & $\left(z_{1}=0.89\right)$ & & $\left(z_{2}=4.20\right)^{++}$ & & \\
\hline & & & & & $(1-14)$ & & \\
\hline \multirow[t]{3}{*}{ S. goldsackii** $(3,79)$} & 40 & 20 || (94.9\%) & $30.9 \pm 2.4$ & 31 & $9.2 \pm 3.6$ & 8 & $96.7-99.5 \%$ \\
\hline & & 18 II + 1 IV (3.8\%) & $\left(z_{1}=0.42\right)$ & & $\left(z_{2}=3.40\right)^{++}$ & & \\
\hline & & 19 || + 2 I (1.3\%) & & & $(2-19)$ & & \\
\hline \multirow[t]{3}{*}{ S. melanopotamicus** $(6,76)$} & $40+0-1 B$ & 20 || (98.7\%) & $33.5 \pm 2.1$ & 33 & $8.2 \pm 3.5$ & 10 & $93.7-99.6 \%$ \\
\hline & & 18 II + 1 IV (1.3\%) & $\left(z_{1}=-1.56\right)$ & & $\left(z_{2}=3.74\right)^{++}$ & & \\
\hline & & & & & $(0-16)$ & & \\
\hline \multirow[t]{3}{*}{ S. microphyllus** $(2,10)$} & $80+0-6 B$ & 40 ॥ (60\%) & $47.2 \pm 5.8$ & 46 & $4.6 \pm 3.3$ & 2 & $98.5-99.5 \%$ \\
\hline & & 38 II + 1 IV (30\%) & $\left(z_{1}=-3.64\right)^{++}$ & & $\left(z_{2}=4.86\right)^{++}$ & & \\
\hline & & 36 II + 2 IV (10\%) & & & $(1-9)$ & & \\
\hline \multirow[t]{4}{*}{ S. pampeanus $(3,24)$} & $40+0-1 B$ & 20 ॥ (75\%) & $27.0 \pm 2.6$ & 27 & $2.5 \pm 2.1$ & 1 & $98.3-98.7 \%$ \\
\hline & & 19 II + 2 I (16.7\%) & $\left(z_{1}=-0.99\right)$ & & $\left(z_{2}=5.55\right)^{++}$ & & \\
\hline & & 17 || + 6 | (4.15\%) & & & $(0-7)$ & & \\
\hline & & 18 II + 1 IV (4.15\%) & & & & & \\
\hline \multirow[t]{7}{*}{ S. pinnatus $(4,36)$} & $80+0-10 B$ & 40 || (36.1\%) & $59.7 \pm 3.6$ & 60 & $10.4 \pm 4.2$ & 11 & $98.8-99.6 \%$ \\
\hline & & 38 II + 1 IV (22.2\%) & $\left(z_{1}=-0.06\right)$ & & $\left(z_{2}=6.62\right)^{++}$ & & \\
\hline & & 36 II + 2 IV (19.4\%) & & & $(3-20)$ & & \\
\hline & & 32 II + 4 IV (8.3\%) & & & & & \\
\hline & & 34 II + 3 IV (5.5\%) & & & & & \\
\hline & & 38 II + 1 III + 1 I (5.5\%) & & & & & \\
\hline & & 32 II + 3 IV + 4 I (3\%) & & & & & \\
\hline
\end{tabular}


Table 1 Meiotic analysis and pollen stainability of entities belonging to different Subseries of Senecio sect. Senecio (Continued)

\begin{tabular}{|c|c|c|c|c|c|c|c|}
\hline S. ragonesei* $(3,87)$ & 40 & $\begin{array}{l}20 \text { || (96.6\%) } \\
19 \|+2 \mid \text { | (3.4\%) }\end{array}$ & $\begin{array}{l}30.4 \pm 1.6 \\
\left(z_{1}=0.23\right)\end{array}$ & 30 & $\begin{array}{l}4.9 \pm 2.1 \\
\left(z_{2}=4.76\right)^{++} \\
(1-10)\end{array}$ & 5 & $81.6-98.6 \%$ \\
\hline S. riojanus ${ }^{* *}(1,1)$ & 40 & without data & & & & & $99.40 \%$ \\
\hline S. rudbeckiffolius $(7,98)$ & $40+0-6 B$ & $\begin{array}{l}20 \text { || (85.8\%) } \\
18 \text { II + } 1 \text { IV (7.1\%) } \\
16 \text { II + } 2 \text { IV (3.1\%) } \\
19 \text { || + } 2 \text { I (2\%) } \\
18 \text { || + } 4 \text { I (1\%) } \\
15 \text { || + } 1 \text { IV + } 1 \text { VI (1\%) }\end{array}$ & $\begin{array}{l}28.8 \pm 2.5 \\
\left(z_{1}=-0.48\right)\end{array}$ & 30 & $\begin{array}{l}4.6 \pm 2.4 \\
\left(z_{2}=4.88\right)^{++} \\
(0-13)\end{array}$ & 4 & $98.2-98.7 \%$ \\
\hline S. subulatus var. erectus ${ }^{* *}(1,4)(6,43)$ & 40 & 20 II (100\%) & $\begin{array}{l}24.5 \pm 3.0 \\
\left(z_{1}=-2.46\right)^{++}\end{array}$ & 27 & $\begin{array}{l}1.2 \pm 1.5 \\
\left(z_{2}=5.93\right)^{++} \\
(0-3)\end{array}$ & 0 & $71.50 \%$ \\
\hline & $80+0-9 B$ & $\begin{array}{l}38 \text { II + } 1 \text { IV (34.9\%) } \\
40 \text { II (27.8\%) } \\
36 \text { II + } 2 \text { IV (12\%) } \\
34 \text { II + } 3 \text { IV (4.6\%) } \\
30 \text { II + } 5 \text { IV (4.6\%) } \\
37 \text { II + } 1 \text { IV + } 2 \text { I (2.3\%) } \\
39 \text { |I + } 2 \text { I ( } 2.3 \%) \\
38 \text { II + } 4 \text { I (2.3\%) } \\
35 \text { II + } 1 \text { VI + } 1 \text { IV (2.3\%) } \\
35 \text { II + } 1 \text { IV + } 2 \text { II (2.3\%) } \\
35 \text { II + } 2 \text { IV + 2 I (2.3\%) } \\
32 \text { II + } 4 \text { IV(2.3\%) }\end{array}$ & $\begin{array}{l}54.4 \pm 6.6 \\
\left(z_{1}=-1.57\right)\end{array}$ & 55 & $\begin{array}{l}5.3 \pm 3.7 \\
\left(z_{2}=7.75\right)^{++} \\
(1-14)\end{array}$ & 3 & $90-95 \%$ \\
\hline S. subulatus var. salsus** $(1,10)$ & 80 & $\begin{array}{l}34 \text { II + } 3 \text { IV (50\%) } \\
36 \text { II + 2 IV (30\%) } \\
32 \text { II + } 4 \text { IV (20\%) }\end{array}$ & $\begin{array}{l}62.0 \pm 4.8 \\
\left(z_{1}=0.76\right)\end{array}$ & 54 & $\begin{array}{l}11.5 \pm 3.6 \\
\left(z_{2}=6.36\right)^{++} \\
(7-16)\end{array}$ & 16 & $98.50 \%$ \\
\hline S. subulatus var. subulatus* $(4,81)(3,16)$ & $40+0-1 B$ & $\begin{array}{l}20 \text { II (95.1\%) } \\
19 \text { II + } 2 \text { I (3.7\%) } \\
18 \text { II + } 1 \text { IV (1.2\%) } \\
38 \text { II + } 1 \text { IV (25\%) } \\
34 \text { II + } 3 \text { IV (25\%) } \\
36 \text { II + } 2 \text { IV (18.75\%) } \\
40 \text { II (6.25\%) } \\
32 \text { II + } 4 \text { IV (6.25\%) } \\
39 \text { II + 2 I (6.25\%) } \\
37 \text { II + } 1 \text { IV + 2 I (6.25\%) } \\
32 \text { II + } 3 \text { IV + } 4 \text { I (6.25\%) }\end{array}$ & $\begin{array}{l}55.9 \pm 3.2 \\
\left(z_{1}=-1.01\right)\end{array}$ & 58 & $\begin{array}{l}3.4 \pm 2.8 \\
\left(z_{2}=5.23\right)^{++} \\
(0-13) \\
7.3 \pm 4.5 \\
\left(z_{2}=7.30\right)^{++} \\
(1-20)\end{array}$ & 1 & $90-99.4 \%$ \\
\hline S. uspallatensis $(13,123)$ & $80+0-5 B$ & $\begin{array}{l}40 \text { II (34.1\%) } \\
38 \text { II + } 1 \text { IV (21.95\%) } \\
36 \text { II + } 2 \text { IV (20.32\%) } \\
34 \text { II + } 3 \text { IV (4.95\%) } \\
39 \text { |I + } 2 \text { I (3.25\%) }\end{array}$ & $\begin{array}{l}52.7 \pm 5.8 \\
\left(z_{1}=-2.21\right)^{++}\end{array}$ & 52 & $\begin{array}{l}7.6 \pm 4.8 \\
\left(z_{2}=7.23\right)^{++} \\
(0-21)\end{array}$ & 5 & $72.9-99.9 \%$ \\
\hline
\end{tabular}




\section{Serie Sandwithiani (Cabrera) Cabrera et S.E.Freire}

S. viridis var. radiatus* $(8,143)$

S. viridis var. viridis** $(1,19)$

$$
40+0-1 B
$$$$
80+0-2 B
$$$$
34
$$$$
37 \text { II + } 1 \text { IV + 2 I (3.25\%) }
$$$$
34 \text { II + } 2 \text { IV + } 1 \text { III + } 1 \text { I (1.63\%) }
$$$$
35 \text { II + } 2 \text { IV + } 2 \text { I (1.63\%) }
$$$$
32 \text { II + } 4 \text { IV (1.63\%) }
$$$$
38 \mathrm{II}+4 \text { I (0.81\%) }
$$$$
36 \text { II + } 1 \text { IV + } 4 \text { I (0.81\%) }
$$$$
33 \text { II + } 3 \text { IV + } 2 \text { I (0.81\%) }
$$$$
33 \text { II }+2 \text { IV + } 2 \text { III (0.81\%) }
$$$$
33 \|+1 \mathrm{VI}+2 \mathrm{IV}(0.81 \%)
$$$$
32 \text { II }+3 \text { IV + } 4 \text { I (0.81\%) }
$$$$
31 \mathrm{I}+1 \mathrm{X}+2 \mathrm{IV}(0.81 \%)
$$$$
31 \mathrm{II}+1 \mathrm{VI}+2 \mathrm{IV}+1 \mathrm{III}+1 \text { I (0.81\%) }
$$$$
30 \text { || + } 5 \text { IV }(0.81 \%)
$$

$$
\begin{aligned}
& 20 \text { || (94.4\%) } \\
& 18 \text { II + } 1 \text { IV (3.5\%) } \\
& 19 \text { || + } 2 \text { I (2.1\%) }
\end{aligned}
$$

$$
32 \text { II + } 4 \text { IV (21\%) }
$$$$
40 \text { ॥ (10.4\%) }
$$$$
38 \text { II + } 1 \text { IV (10.4\%) }
$$$$
39||+2 \text { | (5.3\%) }
$$$$
36 \text { II }+2 \text { IV (5.3\%) }
$$$$
36 \text { II + } 1 \text { IV + } 1 \text { III + } 1 \text { I (5.3\%) }
$$$$
30 \mathrm{II}+5 \mathrm{IV}(5.3 \%)
$$$$
30 \|+4 \mathrm{IV}+1 \mathrm{II}+1 \mathrm{I}(5.3 \%)
$$$$
28 \|+5 \mathrm{IV}+1 \mathrm{II}+1 \mathrm{I}(5.3 \%)
$$$$
24 \|+7 \mathrm{IV}+1 \mathrm{II}+1 \mathrm{I}(5.3 \%)
$$

\section{Serie Simplices (Cabrera) Cabrera et S.E.Freire}

S. grisebachii var. grisebachii $(1,9)$

40

S. grisebachii var. leptotus ${ }^{* *}(5,57)$

$40+0-2 B$

20 || (98.2\%)

19 || +2 | (1.8\%)

S. grisebachii var. schizotus ${ }^{* *}(3,37)$

S. hieronymi $(5,90)$

$$
\begin{aligned}
40 \quad & 20 \|(75.7 \%) \\
& 19 \|+2 \text { I (10.8\%) } \\
& 18 \|+1 \text { IV (8.1\%) } \\
& 18 \|+4 \mid(5.4 \%)
\end{aligned}
$$$$
40+0-7 B
$$

$$
\begin{array}{lllll}
31.4 \pm 3.0 & 32 & 5.6 \pm 3.0 & 6 & 94.1-99.7 \% \\
\left(z_{1}=0.68\right) & & \left(z_{2}=4.56\right)^{++} & & \\
& & (0-13) & & \\
58.7 \pm 2.2 & 61 & 13.7 \pm 3.9 & 12 & 98.90 \% \\
\left(z_{1}=0.08\right) & & \left(z_{2}=5.88\right)^{++} & & \\
& & (8-21) & &
\end{array}
$$

$$
\begin{array}{lllll}
27.9 \pm 2.6 & 28 & 6.0 \pm 2.3 & 7 & 91.50 \% \\
\left(z_{1}=-0.94\right) & & \left(z_{2}=4.43\right)^{++} & & \\
& & (2-9) & & \\
24.8 \pm 3.1 & 21 & 3.7 \pm 2.2 & 4 & 97.8-99.8 \% \\
\left(z_{1}=-2.31\right)^{++} & & \left(z_{2}=5.15\right)^{++} & & \\
& & (0-10) & & \\
24.1 \pm 2.6 & 24 & 4.2 \pm 2.3 & 4 & 97.5-99.5 \% \\
\left(z_{1}=-2.36\right)^{++} & & \left(z_{2}=5.01\right)^{++} & & \\
& & (0-9) & & \\
& & & & \\
28.4 \pm 2.9 & 29 & 3.8 \pm 2.0 & 3 & 98.60 \% \\
& & \left(z_{2}=5.12\right)^{++} & &
\end{array}
$$$$
19 \text { || + } 2 \text { | (6.7\%) }
$$$$
18 \text { || + } 1 \text { IV (3.3\%) }
$$ 
Table 1 Meiotic analysis and pollen stainability of entities belonging to different Subseries of Senecio sect. Senecio (Continued)

\begin{tabular}{|c|c|c|c|c|c|c|c|}
\hline \multirow[t]{4}{*}{ S. linariifolius var. subtomentosus ${ }^{* *}(1,46)$} & 40 & 20 ॥ (87\%) & $28.0 \pm 2.6$ & 28 & $3.2 \pm 2.3$ & 5 & without data \\
\hline & & 19 || + 2 | (8.7\%) & $\left(z_{1}=-0.82\right)$ & & $\left(z_{2}=5.32\right)^{++}$ & & \\
\hline & & $18\|+1\|+1 \mid(2.15 \%)$ & & & $(0-9)$ & & \\
\hline & & $18 \|+1$ IV (2.15\%) & & & & & \\
\hline \multirow[t]{3}{*}{ S. octolepis var. saltensis* $(2,41)$} & 40 & 20 \|| (92.7\%) & $25.1 \pm 3.0$ & 24 & $4.8 \pm 2.0$ & 6 & $94.4-99.1 \%$ \\
\hline & & 16 II + 2 IV (4.9\%) & $\left(z_{1}=-2.16\right)^{++}$ & & $\left(z_{2}=4.82\right)^{++}$ & & \\
\hline & & 18 II + 1 IV (2.4\%) & & & $(1-10)$ & & \\
\hline \multicolumn{8}{|l|}{ Serie Viscosi (Baker) Cabrera et S.E.Freire } \\
\hline \multirow[t]{3}{*}{ S. crepidifolius* $(1,17)$} & 40 & $20 \|(88.2 \%)$ & $25.8 \pm 2.8$ & 26 & $4.2 \pm 2.2$ & 2 & without data \\
\hline & & $19 \|+2 \mid(5.9 \%)$ & $\left(z_{1}=-1.73\right)$ & & $\left(z_{2}=4.98\right)^{++}$ & & \\
\hline & & $18 \|+4 \mid(5.9 \%)$ & & & $(1-9)$ & & \\
\hline
\end{tabular}

In the first column. numbers in parentheses indicate the number of individuals and cells. respectively. analyzed in each taxon. Chromosome number (2n); meiotic configurations and corresponding percentage. Media $(\bar{x})$. standard deviation (sd) and mode (M) of total chiasmata per cell and interstitial chiasmata (interstitical ch.). range of instestitial chiasmata in parentheses. both statistics values $z_{1}$ and $z_{2}$ and percentage of pollen stainability are shown *chromosome record already published by the authors.

**new chromosome record.

${ }^{++}$significant values $(\mathrm{p}<0.05)$

$\mathrm{z}_{1}$ : proportion of open bivalents. $\mathrm{z}_{2}$ : proportion of interstitial chiasmata.

bivalents were also marked in the cells used to recombinant analysis (Figure 1A-P).

\section{Meiotic behavior}

Meiotic behavior was carefully examined in all the new recorded entities except in S. riojanus because of the scarce material in adequate maturation condition. The majority of the individuals exhibited bivalents secondarily associated (Figure 1B, E, G-I, K, M-N, P). Heteromorphic bivalents (Figure $1 \mathrm{E}$ ) were observed in all the taxa with $2 \mathrm{n}=40$, with exception of $S$. ganganensis, $S$. linariifolius var. subtomentosus and S. subulatus var. salsus. Completely regular meiosis was seen in Senecio eruciformis var. brachycephalus, S. ganganensis, S. goldsackii, S. grisebachii var. schizotus, S. viridis var. viridis and $S$. subulatus var. erectus. In some species, meiotic irregularities such as, chromosome breakage (Figure 2A); bivalents out of plate at metaphase I (Figure 2B); lagged chromosomes at anaphase I and II; chromosomes excluded to the nucleus at telophase I (Figure 2C) and prophase II (Figure 2D); bridges at Telophase II (Figure 2E); micronuclei at Telophase I, Prophase II, Telophase II (Figure 2H), tetrads (Figure 2I) and microsporocytes (Figure 2F, G) were observed, although infrequently. In species with B chromosomes, they were excluded from the nucleus and remain as micronuclei after Telophase. Meiotic behavior of the other entities included in this paper was described in previous publications (López et al., 2002; 2005; 2008 b). Pollen stainability was higher than $70 \%$ in all the species.

\section{Recombination analysis}

Values of median and mode of chiasmata per cell were similar in all the cases. The statistics z1 was significant $(\mathrm{p}<0.05)$ only in 7 entities (Table 1$)$ and negative in all of them, indicating that the number of open bivalents was higher than the expected by random.

Median and mode of interstitial chiasmata per cell were low for all species analyzed, ranging from 1.2 to 13.7 and from 0 to16 respectively, with high data dispersion. The statistics $\mathrm{z} 2$ was significant $(\mathrm{p}<0.05)$ and positive in all cases, indicating a reduction in the interstitial chiasmata in relation with the expected by random, and as a consequence the predominance of chiasmata in terminal position.

\section{Discussion}

Strong evidence supporting $\mathrm{x}=5$ as the basic chromosome number in the genus Senecio has been recently published (López et al., 2008a). Considering this statement, the species here studied displayed ploidy levels $8 \mathrm{x}$ and $16 \mathrm{x}$, and, chromosome numbers $2 \mathrm{n}=40$ and $2 \mathrm{n}=80$ respectively, both of them in accordance with the modal numbers of the genus (Bolkhovskikh et al., 1974). It is noticeable the existence of two S. subulatus varieties presenting both chromosome numbers. These data represent the first reports of cytotypes for this genus in Argentina. This polymorphic species comprises three varieties coexisting sympatrically in nature, mostly in Mendoza province, but practically indistinguishable, except by minor differences in the capitula. Further analyses of the infraspecific taxa will contribute to solve 



Figure 1 (See legend on next page.) 
(See figure on previous page.)

Figure 1 Cytogenetic analysis of Senecio sect. Senecio taxa. A: S. eruciformis var. brachycephalus, diakinesis with 19 II +2 I. B: S. eruciformis var. eruciformis, metaphase I with 20 II. C: S. grisebachii var. schizotus, diakinesis with 16 II + 1IV + 4 I. D: S. linariifolius var. subtomentosus, diakinesis with 18 II + 1 III + 1 I. E: S. glaber, diakinesis with 20 II. F: S. riojanus, prometaphase II with 20 chromosomes in each pole. G: S. ganganensis, prometaphase I with 20 II. H: S. goldsackii, metaphase I with 20 II. I: S. grisebachii var. leptotus, diakinesis with 20 || +3 B chromosomes (1 IIB + 1 IB). J: S. brasiliensis var. tripartitus, diakinesis with 20 II. K: S. melanopotamicus, diakinesis with 20 II. L S. subulatus var. salsus, diakinesis with 34 II +3 IV. M: S. viridis var. viridis, prometaphase I with 27 II + $5 \mathrm{IV}+1$ III + 3 I, displaying evident secondary association of bivalents. N: S. microphyllus, metaphase I with 38 II + 1 IV + 2 IB. O: S. subulatus var erectus cytotype $2 n=40$, late metaphase I with 20 II. P: S. subulatus var. erectus cytotype $2 n=80$, diakinesis with $30 \mathrm{II}+5 \mathrm{IV}$. Asterisks indicate secondary association of bivalents; white triangles indicate univalents (I); line arrows indicate heteromorphic bivalents; black triangles indicate quadrivalents (IV); tick white arrows indicate trivalents (III); thick black arrows indicate B chromosomes; c: close bivalents; qi: interstitial chiasmata. Bars $=10 \mu \mathrm{m}$.

the taxonomic and cytogenetic controversies but the existence of different ecological or environmental patterns could explain the presence of both cytotypes in the same place (Schönswetter et al., 2007; Suda et al., 2007).

Even when high frequency of multivalents and the meiotic irregularities associated are expected in elevated polyploids, bivalents predominance and consequently regular meiosis were observed in this analysis and in the previous ones conducted in Senecio (López et al., 2002; 2005; 2008a). The documented meiotic irregularities can be mainly consequence of the structural rearrangements occurring between genomes, such as translocations, paracentric inversions, deletions, and insertions among others, which have been recorded for other polyploids by several authors (Stebbins, 1980; Thompson and Lumaret, 1992; Soltis and Soltis, 1993; Comes and Abbott, 1999; López et al., 2002). Frequently, the lagged chromosomes and the micronuclei were associated with B chromosomes suggesting a particular behavior of them to remain excluded from the nucleus. The scarce meiotic irregularities had not, apparently effect over pollen grain integrity as revealing by the high stainaiblity values observed.

The abundance of bivalents linked to their outstanding secondary association revealed a diploidized behavior

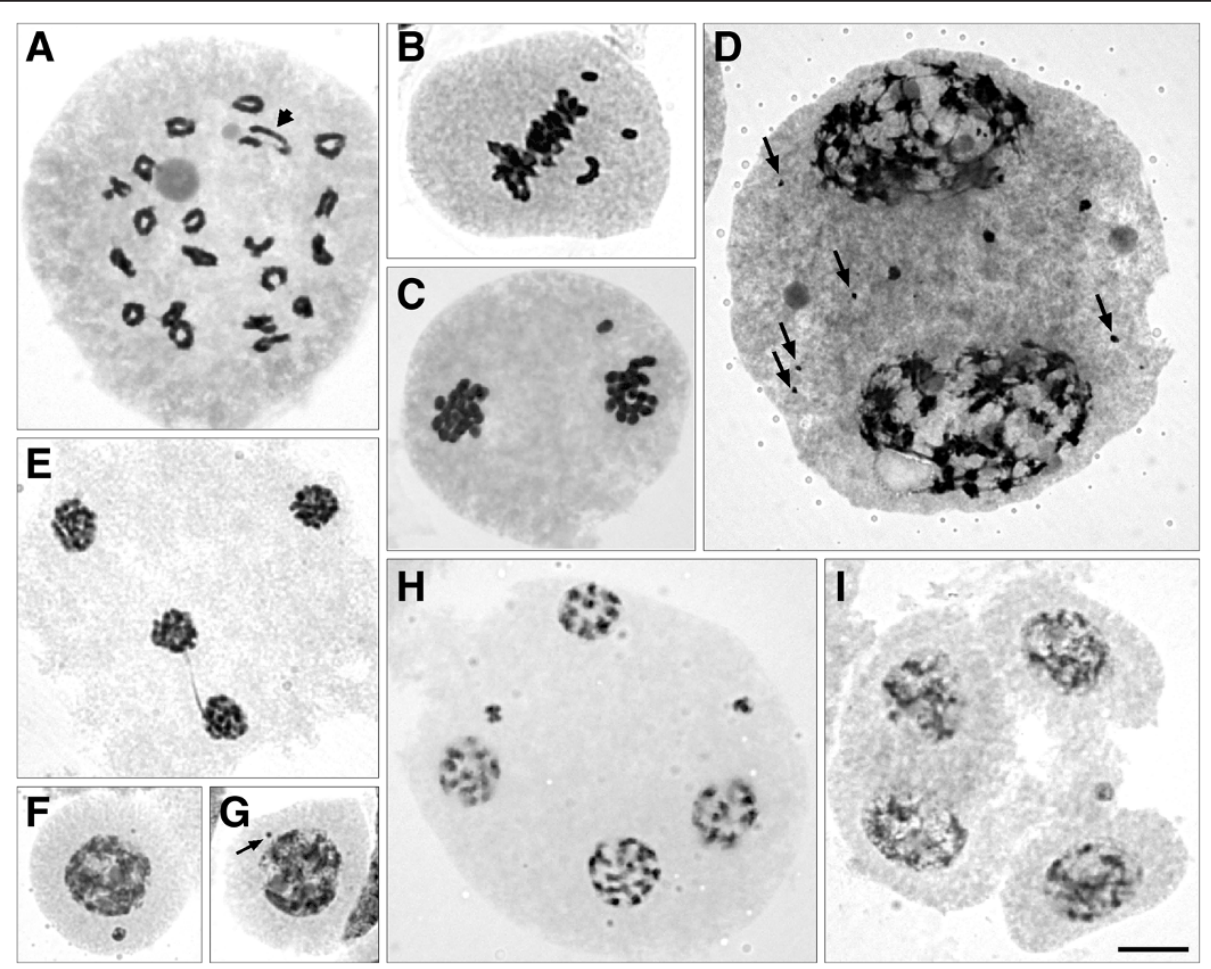

Figure 2 Meiotic behavior of Senecio sect. Senecio taxa. A: S. melanopotamicus, diakinesis with 20 II, arrow indicate chromosome breakage. B: S. goldsackii, metaphase I, 1 II and 2 I out of plate. C: S. melanopotamicus, telophase I, a chromosome not included in a pole. D: S. microphyllus, prophase II with A and B (arrows) chromosomes not included in cell poles. E: S. goldsackii, telophase II with a bridge. F-G: S. subulatus var. erectus, F: microsporocyte with one big micronucleus (A chromosome); G: microsporocyte with one small micronucleus (arrow, B chromosome). H: S. ganganensis, telophase II with micronuclei. I: S. eruciformis var. brachycephalus, tetrads with one micronucleus. Bars $=10 \mu \mathrm{m}$. 
in these species and, this was in accordance with data previously published (Riley and Chapman 1958; López et al., 2002; 2008a). This particularity could be interpreted as reduction in crossing-over and consequently decrease in the number chiasmata per cell. Depletion in the total chiasmata was significant only in some species but the terminal position was preferential in all the Senecio entities analyzed. Both parameters indicate a significant reduction in recombination. In the first case, less chiasmata imply clearly less crossing-over in the second case, restriction to the terminal position limit the interchange to a small segment, keeping most of the chromosome length almost invariable.

Although these polyploids underwent a substantial reduction in genetic recombination, there was not a notorius loss of variability sentencing these species to disappearance. On one hand, chromosome orientation in metaphase I is a source of variability and it is not affected by polyploidy. Conversely, the increase in chromosome number enlarges the potential combinations. On the other hand, polyploids have exclusive resources to obtain variability including hybridization, recurrent formation, genomic reorganization and new expression patterns (Soltis and Soltis, 1993; 1999; Wendel, 2000; Soltis et al., 2003; Kovarik et al., 2005; Tate et al., 2005; Hegarty et al., 2006; Chen et al. 2007; López et al., 2008b). In addition, recombination restricted to chromosome terminal positions could favor the maintenance of adaptative gene combinations over generations.

The surprisingly regular meiosis observed would suggest that intra and intergenomic reorganization process occur quickly and efficiently in the genus Senecio modifying chromosome homology and probably favoring a diploidized behavior. B chromosomes have been linked with this particular chromosome behavior (Gupta, 1981), but this relationship is not evident in Senecio. Moreover, a different factor has been proposed in relation with it, the existence of $\mathrm{Ph}$ like genes (Moore, 1998; Sybenga, 1999; Al-Kaff et al., 2008). Although they have not been described yet in the genus Senecio, their effect on the promoting of diploidized behavior could not be discarded.

\section{Conclusion}

Processes producing diploidized behavior avoid the sterility associated to high polyploids and maintain advantage adaptative allele combinations, ensuring species success, stabilization and establishment in nature (Stebbins, 1980; Thompson and Lumaret, 1992; Comes and Abbott 1999; Soltis and Soltis, 1993, 1999). Especially, in the genus Senecio, the mechanisms of diploidization are accelerated by a strong reduction in crossing over, process evidenced in the present work.

\section{Appendix 1}

List of Senecio specimens analysed, collection data, voucher number and herbaria where they are deposited in parentheses. All the specimens were collected in Argentina.

\section{Subserie Brasiliensis (Cabrera) Cabrera et S.E. Freire}

S. brasiliensis (Spreng.) Less. var. tripartitus (DC.) Baker. Buenos Aires. Pdo. Escobar. Belén de Escobar, MGL 39 (SI), Pdo. Ensenada, Punta Lara, MGL \& CCX 70, 71, 72 (SI)

S. eruciformis J. Rémy var. Eruciformis. Mendoza. Depto. Las Heras. Los Penitentes, AFW \& MGL 1064, 1065 (SI),

S. eruciformis J. Rémy brachycephallus (Phil.) Cabrera. Mendoza Depto. Las Heras. Puente del Inca, AFW \& MGL 1068, 1069 (SI)

S. ganganensis Cabrera. Mendoza Depto. Las Heras. Uspallata, AFW \& MGL 1153 (SI)

S. gilliesianus Hieron. Mendoza Depto. Las Heras. Camino a Papagallos, AFW \& MGL 1032 (SI). Frente al autódromo Gral. San Martín, AFW \& MGL 1038 (SI). Estación Canota, MGL \& AFW 129,130 (SI)

S. glaber Less. var. glaber. Mendoza Depto. San Rafael. Cerro Diamante, AFW \& MGL 1207 (SI),

S. goldsackii Phil. Mendoza Depto. San Rafael entre Sonseado y Cañada Amarilla, AFW \& MGL 1213 (SI). Depto. San Rafael Camino a Volcán Diamante, MGL \& AFW 119 (SI). Depto. San Rafael. Camino a El Sosneado, AFW \& MGL 1093 (SI)

S. melanopotamicus Cabrera. Mendoza Depto. Las Heras. Camino a Uspallata, polígono de tiro militar, AFW \& MGL 1139, 1140, 1141(SI), Qda. de Santa Elena, AFW \& MGL 1188 (SI). Camino a Mina Talcomín, AFW \& MGL 1192, 1193 (SI)

S. microphyllus Phil. Mendoza. Depto. Las Heras. $32^{\circ}$ 31' 15" S; 69'02' 4,8" W; 2360 msm, AFW \& MGL 1018 (SI). Caracoles de Villavicencio, AFW \& MGL 1120 (SI)

S. pampeanus Cabrera. San Luis. Depto. Ayacucho. Quine, MGL55 y 56 (SI). Córdoba. Depto. San Alberto. Camino Altas Cumbres hacia Mina Clavero, AFW 908 (SI)

S. pinnatus Poir. var. Pinnatus. Mendoza. Depto. Luján. Cañada Grande, 8,5 km de Vallecito, AFW \& MGL 1197 (SI). Santiago del Estero. Depto. Capital. Campus de la UCSE, MGL 148, 149, 150 (SI)

S. ragonesei Cabrera. Mendoza. Depto. Las Heras. Camino a Mina Talcomín, AFW \& MGL 1189, 1190 (SI). Depto. San Rafael. Subiendo al Cerro Diamante, AFW \& MGL 1208 (SI)

S. riojanus Cabrera var. Riojanus. Mendoza San Rafael. Puesto Vega del Burro, Ayo. Las Mangas, AFW \& MGL 1211 (SI). 
S. rudbeckiifolius Meyen et Walp. Tucumán. Depto. Tafí, AFW 916, 917, 918 (SI). Co Pelado, camino al Co de La Cruz, AFW 940, 942 (SI). Salta. Depto. Chicoana. Qda. Lapacheta, AMS \& CCX 168 (SI). Depto. Cachi. $6 \mathrm{~km}$ de La Cuesta del Obispo, MGL, CCX \& MNS 194. (SI)

S. subulatus D. Don. ex Hook. et Arn. var. subulatus. Mendoza. Depto. San Carlos. Ruta 40 camino a Agua del Toro, AFW \& MGL 1200,1201 (SI). Depto. San Rafael. Puesto Vega del Burro, Ayo. Las Mangas, AFW \& MGL 1209 (SI). Dique Agua de Toro, MGL \& AFW 123 (SI). Depto. Malargüe. Malargüe, MGL \& AFW 125 (SI). Depto. Las Heras. Camino a Uspallata desde Los Tambillos, MGL \& AFW 142,145 (SI)

S. subulatus D. Don. ex Hook. et Arn. var. erectus Hook. et Arn. Mendoza. Depto. Luján. Camino a Potrerillos, AFW \& MGL 1040, 1045, 1046 (SI). Depto. San Rafael. Dique Agua de Toro, MGL \& AFW 122 (SI). Depto. Las Heras. Camino a Uspallata desde Los Tambillos, MGL \& AFW 144 (SI). Depto. Luján de Cuyo. Camino a Potrerillos, MGL \& AFW 146 (SI). Salta Depto. Cafayate. Alrededores de Cafayate, MGL, CCX \& MNS 171 (SI)

S. subulatus D. Don. ex Hook. et Arn. var. salsus (Griseb.) Cabrera. Salta. Depto. Rosario de Lerma. Ruta 51 Km. 83 hacia Sta. Rosa de Tastil, MGL, CCX \& MNS 213 (SI)

S. uspallatensis Hook. et Arn. Mendoza. Depto. Las Heras, 32。 $31^{\prime} 15^{\prime \prime} \mathrm{S}-69^{\circ} 02^{\prime} 4.8^{\prime \prime} \mathrm{W}$, AFW \& MGL 1013 (SI). Los Hornillos, AFW \& MGL 1024,1025 (SI). Puente del Inca, AFW \& MGL 1070, 1071 (SI). Polvaredas, AFW \& MGL 1078 (SI). Uspallata, Puesto Cuevas Norte, AFW \& MGL 1171,1174 (SI). Caracoles de Villavicencio, MGL \& AFW 132, 133, 134, 135, 137 (SI)

S. viridis Phil. var. viridis. Salta. Depto. Los Andes. Base del Abra de Muñano 24 21' 51,8' S; 66 05' 46,7" W; 3750 msm, MGL,CCX \& MNS 217 (SI)

S. viridis Phil. var. radiatus R. E. Fr. Mendoza. Depto. Las Heras. Qda. del Toro. 32 $28,3^{\prime} \mathrm{S} ; 6^{\circ} 03,5^{\prime} \mathrm{W}$, AFW \& MGL 1137 (SI). 16,6 km de Uspallata hacia el W. 32 26,7' S; 69 13,9' W; 2407 msm, AFW \& MGL 1148 (SI). Uspallata, $13,2 \mathrm{~km}$ polígono de tiro militar, 32 21,4' S; 69 12,7' W; 2714 msm, AFW \& MGL 1163, 1169 (SI). Depto. Las Heras. Pampa de Yalguaráz, 32 $10,2^{\prime} \mathrm{S}$; 69 24,3' W; 2249 msm, AFW \& MGL 1181, 1177 (SI)

\section{Subserie Simplices (Cabrera) Cabrera et S. E. Freire}

S. angustissimus Phil. Neuquén. Depto. Lácar. Cerro Chapelco, arriba del refugio Graeff, AMS et al. 95 (SI)

S. grisebachii Baker var. grisebachii. Buenos Aires. Pdo. Escobar. Camino a Paraná de Las Palmas, MGL $40(\mathrm{SI})$
S. grisebachii Baker var. leptotus Cabrera. Bueno Aires. Pdo. Merlo, MGL 1,3,6,8 (SI). Pdo. Exaltación de La Cruz. Los Cardales, MGL \& AFW 87 (SI)

S. grisebachii Baker var. schizotus Cabrera. Bueno Aires Bs. As. Pdo. Merlo, MGL 10, 34 (SI). Pdo. Escobar. El Cazador, MGL 42 (SI)

S. hieronymi Griseb. Tucumán. Depto. Tafí. San Javier, entrada del Cristo, AFW 926, 927 (SI). Salta. Depto. Chicoana; 3348 msm, AMS \& CCX 178 (SI). Depto. Rosario de Lerma. Costado de ruta $51 \mathrm{Km} .16,5, \mathrm{MGL}$, CCX \& MNS 178 (SI). Depto. Cachi. Ruta 33 Km 66. Parque Nac. Los Cardones, MGL, CCX \& MNS 200 (SI)

S. linariifolius Poepp.ex DC. var. subtomentosus Cabrera. Mendoza. Depto. Las Heras. Cuesta de Bonilla, $32^{\circ} 39,5^{\prime} \mathrm{S} ; 6^{\circ} 11,05^{\prime} \mathrm{W} ; 3087 \mathrm{msm}$, AFW \& MGL 1183 (SI)

S. octolepis Griseb. var. saltensis (Hicken) Cabrera et Zardini. Tucuman Depto. Tafí. Atrás de Loma Pelada, AFW 915 (SI). Salta Depto. Chicoana. Qda. Lapacheta, AMS \& CCX 1692 (SI)

\section{Subserie Viscosi (Baker) Cabrera et S. E. Freire}

S. crepidifolius DC. Salta. Depto. Santa Victoria. Abra de Lizoite. Ruta 7 Km 54; 4500 msm, AMS \& CCX 222(SI)

\section{Competing interests}

The authors declare that they have no competing interests.

\section{Authors' contributions}

$M L$ participated in the study design, carried out the cytogenetic preparations, performed the statystical analysis and drafted the manuscript. CX coordinated the study and helped to draft the manuscript. LP revisied the manuscript critically for important intellectual content. AW conceived of the study, and participated in the analysis and interpretation of data. All authors read and approved the final manuscript.

\section{Acknowledgements}

This work was supported by grants from the National Research Council (CONICET), the National University of Buenos Aires and the Myndel Botanical Foundation. The authors are grateful to Dr. Fernando Zuloaga and personal of the Botanical Institute Darwinion (IBODA), Dra. Marta Arias from Miquel Lillo Foundation, Ing. Agr. Fidel Roig t, Ing. Agr. Iris Peralta, Sr. Gualberto Zalazar and Sr. Juan Antunez from IADIZA. They also thank Dr. Javier Calcagno for advice in statistical matters. AFW would like to thank Dr. Roberto Kiesling who kindly invited him to a trip collection at the San Juan Province.

\section{Author details}

${ }^{1}$ CONICET, Laboratorio de Citogenética y Evolución (LACyE), Departamento de Ecología, Genética y Evolución, Facultad de Ciencias Exactas y Naturales, Universidad de Buenos Aires, Ciudad Universitaria, Pabellón 2, $4^{\circ}$ piso, Int. Güiraldes 2620, C1428EHA, Buenos Aires, Argentina. ${ }^{2}$ CIC-PBA, Laboratorio de Etnobotánica y Botánica Aplicada (LEBA), Facultad de Ciencias Naturales y Museo, Universidad Nacional de La Plata, calle 64 Nº 3, 1900, La Plata, Argentina. ${ }^{3}$ Current address: Instituto de Biotecnología, Instituto Nacional de Tecnología Agropecuaria (INTA), Dr. N. Repetto y Los Reseros s/n, 1686, Hurlingham, Argentina. 'Laboratorio de Citogenética y Evolución (LACyE), Departamento de Ecología, Genética y Evolución, Facultad de Ciencias Exactas y Naturales, Universidad de Buenos Aires, Ciudad Universitaria, Pab. II, $4^{\circ}$ piso. Lab 61, Intendente Güiraldes 2160, (C1428EHA), Buenos Aires, Argentina.

Received: 2 September 2011 Accepted: 12 November 2012 Published: 27 August 2013 


\section{References}

Alexander MP (1969) Differential staining of aborted and non-aborted pollen. Stain Technol 44:117-122

Al-Kaff N, Knight R, Bertin I, Foote T, Hart N, Griffiths S, Moore G (2008) Detailed dissection of the chromosomal region containing the Ph1 locus in wheat Triticum aestivum: with deletion mutants and expression profiling Ann Bot 101:863-872

Ashton PA, Abott RJ (1992) Multiple origins and genetic diversity in the newly arisen allopolyploid species, Senecio cambrensis Rosser, (Compositae). Heredity 68:25-32

Bolkhovskikh Z, Grif V, Matvejeva O, Zakharyyeva O (1974) In: Koeltz P (ed) Chromosome numbers of flowering plants. Academy of Science USSR, Reprint, Koenigstein, Leningrad

Bremer K (1994) Asteraceae: cladistics and classification. Timber Press, Oregon, p 928 Cabrera AL, Freire SE, Ariza Espinar L (1999) Asteraceae. In: Flora Fanerogámica Argentina 62, Parte XIII. ProFlora CONICET, Buenos Aires, p 188

Chen ZJ, Ha M, Soltis D (2007) Polyploidy: genome obesity and its consequences. New Phytol 174:717-720

Comes HP, Abbott RJ (1999) Reticulate evolution in the Mediterranean species complex of Senecio sect. Senecio: uniting phylogenetic and population-level approaches. In: Hollingsworth PM, Bateman RM, Gornall RJ (eds) Molecular Systematics and Plant Evolution. Taylor \& Francis, London, p 485

Daniel WW (1999) Bioestadística. Base para el análisis de las ciencias de la salud. UTEHA. Noriega, México, 878 pp

Grant VS (1989) Especiación Vegetal. Limusa, México, p 587

Gupta PP (1981) Suppression of multivalent formation by chromosomes in natural and artificial autopolyploids of scurvy-grass (Cochlearia L.). Theor Appl Genet 59:221-223

Hegarty MJ, Barker GL, Wilson ID, Abbott RJ, Edwards KJ, Hiscock SJ (2006) Transcriptome shock after interspecific hybridization in Senecio is ameliorated by genome duplication. Curr Biol 16:1652-1659

Heslop-Harrison (Pat) JS, Schwarzacher T (2011) Organisation of the plant genome in chromosomes. Plant J 66:18-33

Kovarik A, Pires JC, Leitch AR, Lim KY, Sherwood AM, Matyasek R, Rocca J, Soltis DE, Soltis PS (2005) Rapid concerted evolution of nuclear ribosomal DNA in two Tragopogon allopolyploids of recent and recurrent origin Genetics 169:931-944

Lawrence ME (1980) Senecio L. (Asteraceae) in Australia: chromosome numbers and the ocurrence of polyploidy. Aust J Bot 28:151-165

Lawrence ME (1985) Senecio L. (Asteraceae) in Australia: nuclear DNA amounts. Aust J Bot 33:221-232

López MG, Wulff AF, Xifreda CC (2002) Chromosome contribution to andean polyploid species of Senecio (Asteraceae) from Argentina. Caryologia 55:27-35

López MG, Wulff AF, Poggio L, Xifreda CC (2005) Chromosome numbers and meiotic studies in species of Senecio (Asteraceae) from Argentina. Bot J Linn Soc 148:465-474

López MG, Wulff AF, Poggio L, Xifreda CC (2008a) South African weed Senecio madagascariensis (Asteraceae) in Argentina: relevance of chromosome studies to its systematics. Bot J Linn Soc 158:613-620

López MG, Wulff AF, Xifreda CC (2008b) Natural hybrids in Senecio (Asteraceae): new records from Argentina. Plant Biosyst 142:185-190

Moore G (1998) To pair or not to pair: chromosome pairing and evolution. Curr Opin Plant Biol 1:116-122

Nordenstam B (2007) Senecio. In: Kubitzki (ed) The families and genera of vascular plants VIII. Flowering plants. Eudicots. Asterales. Springer, Berlin, pp 208-588

Núñez O (1968) An acetic-haematoxylin squash method for small chromosomes. Caryologia 21:115-119

Pelser PB, Nordenstam B, Kadereit JW, Watson LE (2007) An ITS phylogeny of tribe Senecioneae (Asteraceae) and a new delimitation of Senecio L. Taxon 56:1077-1104

Riley R, Chapman V (1958) Genetic control of the citologically diploid behaviour of hexaploid wheat. Nature 182:713-715

Schönswetter P, Lachmayer M, Lettner C, Prehsler D, Rechnitzer S, Reich DS, Sonnleitner M, Wagner I, Hülber K, Schneeweiss GM, Trávníček P, Suda J (2007) Sympatric diploid and hexaploid cytotypes of Senecio carniolicus (Asteraceae) in the Eastern Alps are separated along an altitudinal gradient. J Plant Res 120:721-725

Soltis DE, Soltis PS (1993) Molecular data and the dynamic nature of polyploidy. Crit Rev Plant Sci 12:243-273
Soltis DE, Soltis PS (1999) Polyploidy: recurrent formation and genome evolution. Trends Ecol Evol 14:348-352

Soltis DE, Soltis PS, Tate JA (2003) Advances in the study of polyploidy since Plant Speciation. New Phytol 161:173-191

Stebbins GL (1980) Unsolved problems and prospects. In: Lewis WH (ed) Polyploidy. Plenum Press, NY, p 583

Suda J, Weiss-Schneeweiss H, Tribsch A, Schneeweiss GM, Trávníček P, Schönswetter P (2007) Complex distribution patterns of di-, tetra-, and hexaploid cytotypes in the European high mountain plant Senecio carniolicus (Asteraceae). Am J Bot 94:1391-1401

Sybenga I (1999) What makes homologous chromosomes find each other in meiosis? A review and a hypothesis. Chromosoma 108:209-219

Tate JA, Soltis DE, Soltis PS (2005) Polyploidy in plants. In: Gregory TR (ed) The Evolution of the Genome. Elsevier Academic Press, London, p 740

Thompson JD, Lumaret R (1992) The evolutionary dynamics of polyploid plants: origins, establishment and persistence. Trends Ecol Evol 7:302-307

Wendel JF (2000) Genome evolution in polyploids. Plant Mol Biol 42:225-249

\section{doi:10.1186/1999-3110-54-20}

Cite this article as: Lopez et al:: Deep cytogenetics analysis reveals meiotic recombination depletion in species of Senecio (Asteraceae). Botanical Studies 2013 54:20.

\section{Submit your manuscript to a SpringerOpen ${ }^{\circ}$ journal and benefit from:}

- Convenient online submission

- Rigorous peer review

- Immediate publication on acceptance

- Open access: articles freely available online

- High visibility within the field

- Retaining the copyright to your article

Submit your next manuscript at $\gg$ springeropen.com 